12. Kazdovà L, V ràna A, Matejckovà M, Vidlàkovà M (1994) Increased lipid peroxidation in an experimental model of metabolic syndrome X: effect of dietary oils. Diabetologia 37 [Suppl 1]: A 533 (Abstract)

13. Paolisso G, D'Amore A, Giugliano D, Ceriello A, Varricchio M, DÓnofrio F (1993) Pharmacological doses of vitamin $\mathrm{E}$ improve insulin action in healthy subjects and noninsulin dependent diabetic subjects. Am J Clin Nutr 57: 650-656

14. Paolisso G, D'Amore A, Balbi V et al. (1994) Plasma vitamin $\mathrm{C}$ affects glucose homeostasis in healthy subjects and non-insulin dependent diabetics. Am J Physiol 266: E261E.268

15. Fujiwara T, Yoshioka S, Yoshioka T, Ushiyama I, Horikoshi H (1988) Characterization of new oral antidiabetic agent CS-045: studies in KK and ob/ob mice and Zucker fatty rats. Diabetes 37: 1549-1558

16. Nolan JJ, Ludvik B, Beerdsen P, Joyce M, Olefsky J (1994) Improvement in glucose tolerance and insulin resistance in obese subjects treated with troglitazone. $\mathrm{N}$ Engl J Med 331: 1188-1193

17. Muchmore DB, Little SA, deHaen C (1982) Counterregulatory control of intracellular hydrogen peroxide production by insulin and lipolitic hormones in isolated rat epididymal fat cells: a role for free fatty acids. Biochemistry 21 : 3886-3892

18. Hayes GR, Lockwood DH (1987) Role of insulin receptor phosphorylation in the insulinomimetic effects of hydrogen peroxide. Proc Natl Acad Sci USA 84: 8115-8119

19. Heffetz D, Bushkin J, Dror R, Zick Y (1990) The insulinomimetic agent $\mathrm{H}_{2} \mathrm{O}_{2}$ and vanadate stimulate protein tyrosine phosphorylation in intact cells. J Biol Chem 265: 2896-2902

20. Yin X, Davison AJ, Tsang SS (1992) Vanadate-induced gene expression in mouse C127 cells: roles of oxygen derived active species. Mol Cell Biochem 115: 85-96

\section{Could coenzyme Q10 and L-carnitine be a treatment for diabetes secondary to 3243 mutation of mtDNA?}

\begin{abstract}
Dear Sir,
Maternally-inherited "diabetes and deafness syndrome" has been related to a point mutation of mtDNA leading to an $A$ to $\mathrm{G}$ transition at position 3243 in the tRNA leucine gene [1-9]. This mutation has been previously observed in patients with MELAS (mitochondrial myopathy, encephalopathy, lactic acidosis and stroke-like episodes). In this disease, as in other mitochondrial myopathies, treatment by coenzyme Q10 has been shown to dramatically improve muscle oxidative metabolism in some patients $[10-14]$. We wondered whether coenzyme Q10 or related compounds which improve mitochondrial oxidative processes might be useful in the treatment of this type of diabetes. Accordingly, we treated a diabetic patient who exhibited the 3243 mutation with a combination of coenzyme Q10 $(150 \mathrm{mg} /$ day) and L-carnitine ( $2 \mathrm{~g} /$ day $)$ for 6 months in order to evaluate whether improvement of glucose tolerance as well as muscle oxidative functions could be observed.

The patient was a 49-year-old woman who had a $3243 \mathrm{mu}-$ tation in the tRNA leucine gene identified with a combination of maternally-inherited diabetes, deafness and atypical pigmentary retinitis. Non-insulin-dependent diabetes was diagnosed at the age of 25 years and insulin treatment had to be introduced at the age of 40 years after oral hypoglycaemic agent failure. Of the total mtDNA, $11 \%$ of that in blood cells and $74 \%$ of that in muscle was found to be mutated. Muscle impairment had been diagnosed by pathology and ${ }^{31} \mathrm{P}$ nuclear magnetic resonance spectroscopy. The ${ }^{31} \mathrm{P}$ magnetic resonance spectroscopy data were recorded throughout a standardized rest-exercise-recovery protocol as previously described [15]. Low residual insulin secretion was assessed by C-
\end{abstract}

Corresponding author: Professor B. Vialettes, Service de Nutrition, Maladies Métaboliques et Endocrinologie, Centre Hospitalier Régional et Universitaire de Marseille, Hôpital Sainte Marguerite, 270 Boulevard Sainte Marguerite, F-13274 Marseille Cedex 09, France peptide measurement before and after $\mathrm{i}$. v. injection of $1 \mathrm{mg}$ of glucagon (Novo Nordisk laboratory Gentofte, Denmark).

The effect of the treatment on glucose tolerance at 3 and 6 months is summarized in Table 1 . During coenzyme Q10 and L-carnitine administration metabolic post-stimulative Cpeptide values did not change. In contrast, at the muscular level the patient felt better and ${ }^{31} \mathrm{P}$ NMR spectroscopy showed an improvement in oxidative metabolism. Metabolic changes were recorded before and after 3 months of treatment. Decreased phosphocreatine/inorganic phosphate $(\mathrm{PCr} / \mathrm{Pi})$ ratio measured at rest, before treatment, indicated an impaired muscle energy state, while after palliative therapy, normalization of the value reflected the improvement of oxidative metabolism. Similarly, ADP concentration, calculated from the creatine kinase equilibrium, returned to normal after treatment (35.68 vs $9.87 \mu \mathrm{mol} / \mathrm{l})$. During the 3 -min exercise of the forearm flexor muscles, glycolysis-induced $\mathrm{pH}$ decrease was large (6.23) compared to the pre-treatment value (6.63) whereas a trend towards a limitation of the PCr breakdown (20.98 vs $15.36 \mathrm{mmol} / \mathrm{l}$ ) was observed. Kinetics of $\mathrm{PCr} / \mathrm{Pi}$ recovery, closely associated with the mitochondrial function, was slower than normal before treatment, as a manifestation of oxidative impairment. Taking into account the effect of end-of-exercise $\mathrm{pH}$ on recovery processes [16], the $\mathrm{PCr} / \mathrm{Pi} \mathrm{ki}$ netics returned to normal upon treatment, further confirming the positive effect of coenzyme $Q$ palliative therapy upon muscular oxidative metabolism. Finally, the clinical tolerance was

Table 1. Effects of treatment by coenzyme Q10 (150 mg/day) and L-carnitine ( $2 \mathrm{~g} /$ day)

\begin{tabular}{lcccc}
\hline & \multicolumn{4}{l}{ Month of therapy } \\
\cline { 2 - 5 } & -6 & 0 & 3 & 6 \\
\hline $\begin{array}{l}\text { Daily insulin dose } \\
\text { (IU/day) }\end{array}$ & 92 & 100 & 92 & 106 \\
$\begin{array}{l}\text { Basal C-peptide } \\
\text { (nmol/1) }\end{array}$ & 0.17 & 0.22 & 0.15 & 0.10 \\
$\begin{array}{l}\text { Post-stimulative } \\
\text { C-peptide (nmol/l) }\end{array}$ & 0.23 & 0.22 & 0.30 & 0.15 \\
HbA $_{1 \mathrm{c}}(\%)$ & 8.1 & 7.9 & 8.2 & 8.1 \\
\hline
\end{tabular}


fair; the patient complained only of moderate itching, which did not lead her to drop out of the study.

These results show that short-term treatment with coenzyme Q10 and L-carnitine, while acting on mitochondrial muscle functions, were unable to restore insulin secretion and/or insulin sensitivity in our patient. This discrepancy in effectiveness of the treatment on these two tissues suggests that the impairment of muscle oxidative processes is probably not involved in the glucose intolerance in this disease. This therapeutic failure, however does not definitely mean that coenzyme Q10 is not of potential benefit in the management of diabetes secondary to mitochondriopathy. It is possible that pancreatic beta cells are less sensitive and in need of a higher dosage of coenzyme Q10 for a longer duration in order to improve mitochondrial functions. In addition, we can hypothesize that treatment was introduced too late in the natural course of the disease. Katagiri et al. [4] have shown that there is a progressive loss of insulin secretion in some subjects with the 3243 mutation. The insulin secretion in our patient was reduced to levels usually observed in classic insulin-dependent diabetes, suggesting that there was a profound loss of beta cells. It is probable that treatment applied at earlier stages, such as during either glucose intolerance or non-insulin-dependent diabetes, may improve insulin production. Because these drugs are well tolerated and their beneficial effect on other tissues such as muscle suggest extending such a clinical trial to patients with less severe pancreatic lesions.

Yours sincerely,

P.Silvestre-Aillaud, D.BenDahan, V.Paquis-Fluckinger, J. Pouget, J.F. Pelissier, C. Desnuelle, P. J. Cozzone, B. Vialettes

\section{References}

1. Alcolado JC, Majid A, Brockington M et al. (1994) Mitochondrial gene defects in patients with NIDDM. Diabetologia $37: 372-376$

2. Gerbitz KD, Paprotta A, Jaksch M, Zierz S, Drechsel J (1993) Diabetes mellitus is one of the hetereogenous phenotypic features of a mitochondrial DNA point mutation within the tRNA ${ }^{\text {leu }}$ (UUR) gene. FEBS Lett 321: 194-196

3. Kadowaki T, Kadowaki H, Mori Y et al. (1994) A subtype of diabetes mellitus associated with a mutation of mitochondrial DNA. New Engl J Med 370: 962-968

4. Katagiri H, Asano T, Ishihara H et al. (1994) Mitochondrial diabetes mellitus: prevalence and clinical characterization of diabetes due to mitochondrial tRNA ${ }^{\text {leu}}($ UUR) gene mutation in Japanese patients. Diabetologia 37: 504-510

5. Kishimoto M, Hashiramoto M, Araki S et al. (1995) Diabetes mellitus carrying a mutation in the mitochondrial tRNA Leu(UUR) gene. Diabetologia 38: 193-200

6. Oka Y, Katagari H, Yasaki Y, Murase T, Kobayashi T (1993) Mitochondrial gene mutation in islet-cell antibodypositive patients who were initially non-insulin-dependent diabetics. Lancet 342: 527-528

7. Reardon W, Ross RMJ, Sweeney MG et al. (1992) Diabetes mellitus associated with a pathogenic point mutation in mitochondrial DNA. Lancet 340: 1376-1379

8. Remes AM, Majamaa K, Herva R, Hassinen IE (1993) Adult-onset diabetes mellitus and neurosensory hearing loss in maternal relatives of MELAS patients in a family with the tRNA ${ }^{\text {leu}}(U U R)$ mutation. Neurology 43:1015-2020

9. van den Ouveland JMW, Lemkes HHPJ, Ruitenbeek W et al. (1992) Mutation in mitochondrial tRNA ${ }^{\text {leu}}$ (UUR) gene in large pedigree with maternally transmitted type II diabetes mellitus and deafness. Nature Genet 1: 368-371

10. BenDahan D, Desnuelle C, Vanuxem D et al. (1992) ${ }^{31} \mathrm{P}$ NMR spectroscopy and ergometer exercise test as evidence for muscle oxidative preformance improvement with coenzyme $Q$ in mitochondrial myopathies. Neurology 42: $1203-1208$

11. Bresolin N, Doriguzzi C, Ponzetto et al. (1990) Ubidecarenone in the treatement of mitochondrial myopathies: a multi-center double-blind trial. J Neurol Sci 100: 70-78

12. Thara Y, Namba R, Kuroda S, Sato T, Shirabe T (1989) Mitochondrial encephalopathy (MELAS): pathological study and successful therapy with coenzyme Q10 and idebenone. J Neurol Sci 90: 263-271

13. Nishikawa Y, Takahashi M, Yorifuji S et al. (1989) Longterm coenzyme Q10 therapy for a mitochondrial encephalomyopathy with cytochrome c oxidase deficiency: a ${ }^{31} \mathrm{P}$ NMR study. Neurology 39: 399-403

14. Scarlato G, Bresolin N, Moroni I et al. (1991) Multicenter trial with ubidecarenone: treatment of 44 patients with mitochondrial myopathies. Rev Neurol 147: 542-548

15. BenDahan D, Confort-Gouny S, Kozak-Ribbens G, Cozzone PJ (1990) Heterogeneity of metabolic response to exercise in humans: new criteria of invariance defined by in vivo phosphorus NMR spectroscopy. FEBS Lett 272: 155-158

16. BenDahan D, Confort-Gouny S, Kozak-Ribbens G, Cozzone PJ (1993) Investigation of metabolic myopathies by ${ }^{31} \mathrm{P}$ MRS using a standardised rest-exercise-recovery protocol: a survey of 800 explorations. MAGMA 1: 91-104

\section{Could differences in body mass index and/or insulin sensitivity explain the association between parental diabetic nephropathy and risk of diabetes in offspring?}

Dear Sir,

McCance et al. [1] describe a population-based study of the association between parental diabetes, diabetic nephropathy and risk of diabetes in offspring. Diabetic nephropathy in a parent

Corresponding author: Dr. R. J.Sigal, Section on Epidemiology and Genetics, Joslin Diabetes Center, One Joslin Place, Boston, MA 02215, USA was associated with an increased risk of diabetes in offspring, particularly among offspring under age 35 years. This association persisted after controlling for age, age at onset of parental diabetes and diabetes in the other parent using logistic regression. The authors conclude that "the present results provide support for parental diabetic nephropathy, independent of age at onset of parental diabetes, conferring an increased risk for diabetes in the offspring".

Nowhere in the paper do the authors mention data on the subjects' body mass index (BMI) or degree of adiposity, although such data would certainly have been available to the investigators. The associations between high BMI, insulin resistance, and increased risk of non-insulin-dependent diabetic mellitus are well established [2]. There is also evidence that insulin resistance may cause predisposition to diabetic nephropathy [3-5]. It is thus conceivable that the association observed 